\title{
Correction to: Prognostic impact of pneumonitis after durvalumab therapy in patients with locally advanced non-small cell lung cancer
}

\author{
Ari Nishimura ${ }^{1} \cdot$ Akira Ono $^{1} \cdot$ Kazushige Wakuda $^{1} \cdot$ Takanori Kawabata $^{2} \cdot$ Michitoshi Yabe $^{1} \cdot$ Taichi Miyawaki $^{1}$. \\ Eriko Miyawaki ${ }^{1} \cdot$ Hiroaki Kodama ${ }^{1} \cdot$ Naoya Nishioka ${ }^{1}$. Nobuaki Mamesaya ${ }^{1} \cdot$ Haruki Kobayashi $^{1} \cdot$ Shota Omori $^{1}$. \\ Hirotsugu Kenmotsu ${ }^{1} \cdot$ Tateaki Naito $^{1} \cdot$ Haruyasu Murakami ${ }^{1} \cdot$ Hideyuki Harada $^{3} \cdot$ Toshiaki Takahashi $^{1}$
}

Published online: 8 November 2021

(c) The Author(s) 2021

\section{Correction to: Investigational New Drugs https://doi.org/10.1007/s10637-021-01191-6}

The original version of this article unfortunately contained mistakes which are listed below.

1. Page 3: "The median interval from durvalumab administration until the occurrence or exacerbation of pneumonitis was 39.5 days (range: $14-181$ days). The median interval from the completion of CRT to the occurrence or exacerbation of pneumonitis was 64.5 days (range: 19-202 days)." must be deleted.
2. Page 4: Changed to "The pneumonitis developed at a median interval of 2.1 months (range: 0.5-6.0 months) after the completion of radiotherapy and a median of 0.5 months (range: 0.0-2.6 months) after the final dose of durvalumab."

The original article has been corrected.

Publisher's Note Springer Nature remains neutral with regard to jurisdictional claims in published maps and institutional affiliations.

The original article can be found online at https://doi.org/10.1007/ s10637-021-01191-6.

Akira Ono

a.ono@scchr.jp

1 Division of Thoracic Oncology, Shizuoka Cancer Center, Shizuoka, Japan

2 Clinical Research Center, Shizuoka Cancer Center, Shizuoka, Japan

3 Division of Radiation Oncology, Shizuoka Cancer Center, Shizuoka, Japan 